\title{
THE CONSTITUTIONAL ASPECTS OF THE \\ "PARSON'S CAUSE"
}

F 229

.53

Copy 1

BY

ARTHUR I'. SCOTT

"HKINIHL HKOM POLITICAL SCIFNCH (UARTHRL

VUI. IXXI, Ni. 4. DECEMBER, IOI6

NEW YORK

PUBLISHED BL GINA \& (ONPANY 


\section{THE CONSTITUTTONAL ASPECTS OF THE "PARSON'S CAUSE"}

BV

ARTHUR P. SCOTT

REPRINTED FROM POLITICAL SCIENCE QUARTERLY Vol. XXXI, No. 4, DeсEMBF, 1916

NEW YORK

PUBLISHEI) BY GINN \& COMPANY

I9 6 


\section{THE CONSTITUTIONAL ASPECTS OF THE "PARSON'S CAUSE"}

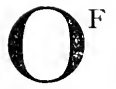

the various important trials and lawsuits during the colonial period few have attracted more attention from the general historian than the cases growing out of the Virginia Two-Penny Act of 1758 . Particularly since the appearance of the Life of Patrick Henry, by Wirt, Henry's

1 Bibliography: Sources.

Perry, W. S., Ilistorical Collections Relating to the American Colonial Church: Virginia. Gives many important letters $1755^{-17} 769$, chiefly from Virginia Clergy to the Bishop of London.

Briefs of John Camm, plaintiff and appellant, and Hansford and Moss, defendants and respondents, before the Privy Council. A transcript from these briefs (from British Museum Additional Manuscripts, no. 36220, folios 52-64) is in the Library of Congress, Hardwicke Papers, vol, $\$_{72}, \mathrm{pp} .201-279$. References in this article are to the transcript.

Fontaine, J. (A. Maury, editor) Memoirs of a Huguenot Family, pp. 418-424. This gives Maury's account of Patrick Henry's speech.

Journals of the Virginia House of Burgesses, (H. R. McElwaine and J. P. Kennedy, editors), $175^{8-1761, ~ p . ~} 285$.

Hening, W. W. The Statutes-at-Large. This is a collection of all the laws of Virginia.

Carter, Landon. A Ietter to the Bishop of London (1759): The Rector Detected (1764).

Bland, Richard. A Letter to the Clergy of Virginia (1760); The Colonel Dismounted (1764). Reprinted in part in the William and Mary Quarterly, vol. xix, pp. $3 \mathrm{I}-4 \mathrm{I}$.

Camm, John. A Single and Distinct View $(1763)$; A Review of the Rector Detected (1764). The pamphlets of Bland, Carter and Camm are summarized in the Report of the Virginia State Library, 1909.

Letter of Virginia Assembly to their Agent (175), in Virginia Magasine of History, vol. $\mathrm{x}$, pp. $347-35^{6}$.

Secondary accounts :

Henry, Wm. Wirt. Patrick Henry: Life, Correspondence and Speeches, vol, i. Morgan, George. The True Patrick Henry.

Tyler, Moses Coit. Patrick Henry.

Wirt, Wm. Sketches of the Life ans: Znaracter of I'atrick Henry (4th edition).

Campbell, Chas. History of the Colony and Ancient Dominion of Virginia.

Meade, Wm. Old Churches, Ministers, and Families of Virginia.

Tyler, Leon G. "The Two Penny Act," in IVilliam and Mary Quarterly, vol. x, pp. ro-3o.

Iloward, (reorge E. Preliminaries of the Revolution, pp. 87-101. 
speech in the "Parson's Cause" has been commonly regarded as a prophecy of the Revolution, "the first intimation of the approaching conflict." " It is thus linked with James Otis's argument in the Writs of Assistance case, when, as John Adams would have it, American independence was born. A somewhat uncritical acceptance of the enthusiastic estimates of Wirt and Adams later resulted in an exaggerated idea of the importance attached to these speeches at the time. Wirt himself shows clearly that when Henry went to Williamsburg the next year " no one knew anything of him." ?

A wider study of contemporary material has resulted in a better appreciation of the real legal, constitutional and social issues involved in the whole Two-Penny-Act controversy, a controversy in which Henry's speech in Parson Maury's case was but a single incident, and not the most important one. Eckenrode, for instance, has brought out the connection of this agitation with the whole movement against the established church, culminating in the Revolutionary separation of church and state. ${ }^{3}$ L. G. Tyler, in an excellent article in which he comments particularly on the determination of the Virginia Assembly to exercise complete control over local taxation, has shown that the underlying question was "the Virginia Constitution under the British Sovereign." ${ }_{4}$ Some important aspects of the case, however, have been generally ignored. Even when the technical points of law involved have been correctly stated, 5 they have not been sufficiently emphasized. The far-reaching constitutional questions involved have thus been obscured, or at best have been stated without further elaboration. ${ }^{6}$

${ }^{1}$ Cooke, Virginia, p. 378. Cf. Campbell's Virginia, p. 518: “Henry's speech . . and the verdict . . . in a certain sense . . the commencement of the Revolution in Virginia." See also Appleton's Cyclopedia of American Bingraphy article, Henry.

2 Wirt's Life of IIenry (4th ed.), p. 76 .

"Report of the Virginia State Library, 1909-10 (Separation of Church and State. Special Report of Dipt. of Archives and History).

' Wm. and Mary' Quarterly', vol. 19, ?. 25.

${ }^{3}$ As in Henry's Henry, I, 34.

'The best accounts are in Tyler's article, Henry's Henry, and Howard's P'reliminaries. 
The outstanding facts in the controversy are too familiar to call for more than a brief restatement. By an Act of Assembly of $\mathrm{I} 748$, confirmed by the King in $\mathrm{I} 75 \mathrm{I}$, the salary of the Virginia clergy was fixed at $\mathrm{I} 6,000$ pounds of tobacco a year. ${ }^{x} \mathrm{By}$ an Act of I753, however, two counties were ordered to pay $£ \mathrm{IOO}$ in Virginia currency instead. ${ }^{2}$ In June 1755 the assembly permitted two counties to pay tobacco levies in money, at a rate to be fixed by the justices of the peace. ${ }^{3}$ Later in the same year a threatened shortage in the tobacco crop led to the enactment of a law, to expire at the end of ten months, allowing the payment in money of all tobacco debts at the rate of two pence a pound. ${ }^{4}$ Some of the clergy protested vigorously at the time, even appealing to the Bishop of London, but, as it turned out, two pence was not far from the market value, and the matter was not pressed. ${ }^{5}$ In 1758 , however, another threatened crop-failure led to a popular demand for relief. The assembly responded on October 12 th by providing that all debts, public and private, contracted on a tobacco basis, might if the debtor so desired be paid in currency at the rate of two pence a pound. The act was limited in operation to a year. ${ }^{6}$ Since the market price of tobacco rose to about six pence, debts were naturally paid for the most part in currency.

The merits or demerits of this act as a piece of legislation are not relevant to the present discussion. It has been extensively denounced; but a very plausible argument can be made out for its justice and expediency as an emergency measure. The important point is that the clergy, rightly or wrongly, felt particularly defrauded; for, while the act was general in terms, they were the greatest proportional losers. ${ }^{7}$ As a body they sent Rev. John Camm to lay their grievances before the King in Council. The Bishop of London supported their cause, and on the recommendation of the Lords of Trade, the King on August IO, I759, disallowed not only the act of I 758 but those

\footnotetext{
'Hening, VI, 88.

${ }^{3}$ Hening, VI, 502.

${ }^{6}$ Perry, pp. 434, 440, 447.

' Perry, p. 442.
}

${ }^{2}$ Ilening, VI, 360 .

${ }^{4}$ llening, VI, 568.

'Hening, VII, 240. 
of 1753 and I 755 also. The disallowance was not, however, officially published in Virginia until June 27, 1760, eight months after the law of $175^{S}$ had expired by limitation. ${ }^{\mathrm{r}}$

Neanwhile many of the clergy had refused the tender of currency as the equivalent of their full salaries, and several ministers now proceeded to sue the tax collectors of their parishes to recover the full market value of the tobacco due under the act of $174 \mathrm{~S}$. The collectors set up the law of 1758 as their sufficient justification for having refused to pay in tobacco, and the issue was squarely joined. The crucial question was perfectly clear: In May of 1759, when salaries for I757-8 were due, was the enactment of October I2, I 758 a valid law of Virginia, as the legislature had obviously intended it should be? The litigation dragged on for six or seven years, accompanied by an acrimonious war of pamphlets and public letters in which the issue was threshed-out from every angle. The clergy were uniformly unsuccessful in the courts, and naturally they felt aggrieved.

Following the lead of Wirt, ${ }^{2}$ later writers have almost unanimously agreed that the clergy had the law all on their side, and that they were defeated only by an appeal to prejudice. The refusal of judges and juries to decide in their favor has been interpreted as a bold act of defiance on the part of the colonists, foreshadowing Revolution. ${ }^{3}$ This view assumes as a matter of course that the disallowance of a law might be, and in this case was, retroactive, thus invalidating all action taken in accordance with that law's provisions. ${ }^{4}$ Such an assumption is entirely unwarranted. Ever since the Crown began the prac-

${ }^{1}$ Perry, pp. 458, 460, 464. Carter and Bland, however, say that many of the clergy acquiesced in the law. Carter's Letter, p. $5 \mathrm{I}$.

2 "The clergy had much the best of the argument. The king in his council took up the sulject, denounced the act of $175 \mathrm{~S}$ as an usurpation, and declared it utterly null and void." Wirt's Ienry (4th ed.), p. 40.

"Meade, Old Churches, I, 2I7; Ilawks, Ecclesiastical Contributions: Virginia, p. II 8 ; Camplell, pp. 5I4, 5 I8.

${ }^{4}$ Bancroft (last ed.) 1II, 65: Cooke, Virginia, p. 381 ; Morgan, True Patrick Henry, p. 61; Grahame, History of the United States (1345) IV, 96, 98. Camplell admits the repeal was not " retrospective." Channing, United States, III, 8; Howard, Preliminaries, p. 99 . 
tice of reviewing colonial legislation, in the later I 7 th century, it had been absolutely clear that disailowance took effect only from the moment when it was announced officially in the colony. All action taken under a law before the proclamation of disallowance was valid. In other words, a disallowance was the exact equivalent of a repeal, and the two words were used interchangeably. ${ }^{2}$ Since the machinery of disallowance was slow moving, an objectionable law might have several years of life before it could be annulled. To prevent this, royal governors were instructed to refuse assent to certain general types of laws unless a clause was inserted suspending their operation until they could be reviewed in England. ${ }^{3}$

Inasmuch as the law of 1758 had expired before Virginia was notified of its disallowance, unbroken precedent seemed to demand that the Virginia judges should regard it as having been in full force and effect in the spring of 1759 . Prima facie, the clergy had no case whatever. Nothing daunted, they boldly attempted to differentiate this case from an ordinary disallowance, arguing that the act of 1758 , although it had the form of a law, had never been binding at all. The original validity of the Two-Penny Act was questioned on two general grounds. It was pointed out in the first place that the king's instructions to the governor specifically restrained him from assenting to any amendment to existing legislation unless the amending act contained a suspending clause. Since the act of $175^{8}$ contained no such clause, it was urged that the governor's commission and instructions

'As early as 1638 Virginia laws were being sent to England for exanination (Cal. endar of Siate Papers, Colonial Series, 1574-1660, Pp. 245, 268) but none appears to have bcen disallowed before the time of Janes II. In October, 1680 , a clause was "excepted" by the king (Calendar State Paper, Colonial Series, I661-1668, p. 1 1 ). In 1687 the assembly denied the king's right of repealing a law by proclamation. Bruce, Institutional History, I, 497. Only after the reorganization of the Board of Trade in 1696 was supervision really systematized.

${ }^{2}$ In 1752 the assembly declared: "As we conceive, according to the ancient constitution and usage of this colony, all laws enacted here. not repugnant to the laws and statutes of Great Britain, have always heen taken and held to be in full force, until your Majesty's disallowance thereof is notified here." Hening, $V, 435$, note. Dickerson, American Colonial Government, p. 226.

${ }^{3}$ Greenc, E. P., Provincial Governor, p. 163: Provincial America, p. 53. 
did not sufficiently authorize and impower the (iovernor, with the Consent of the Council and Creneral Assembly to make the said Act . . . but the said Act, as it tended to suspend the Force and Effect of the Act of Assembly ... [of $\mathrm{I}_{7} \mathrm{~S}$ ] . . which had received his Majesty's Approbation, was contrary to his Majesty's Instructions to his (iovernor, and was therefore null and void from the making thereof, and so declared by the late King by his Order in Council. ${ }^{1}$

In the second place, the act was said to be " void in itself, being contrary to the principles of justice." 2

The issue thus brought before the courts was entirely new. Numerous instances had occurred in which royal governors in Virginia and other colonies had assented to laws in direct violation of their instructions. Occasionally such laws had been confirmed by the king, but usually they had been disallowed, particularly when they amended existing laws which had received formal ratification. The king had signified his "high displeasure" to the governors, and had threatened recall in case instructions were not better obeyed. ${ }^{3}$ But never before had the question been raised of the validity of such laws up to the time of their disallowance. When laws, as was sometimes the case, were disallowed after they had expired by limitation, it was simply by way of expressing emphatic disapproval, with a view to preventing similar action in the future. There seems to have been no expectation that action already taken under these laws would be invalidated by their disallowance. On the contrary, the fact that such laws were in full force, no matter how clearly the governors had violated instructions in signing them, was regarded as a grave danger. ${ }^{4}$ No remedy however seems to have suggested itself except to reiterate threats and

'Camm's Brief, p. 214. (Hardwicke Papers, vol. 872, Transcript Lib. of Cong.). if. Campbell, p. 512.

2Respondents' Brief, p. 267.

${ }^{3}$ Massachusetts Acts and Resolves, II, 127.

The Board of Trade complain (1754) of the practice "which is become too frequent in Your Majestys Colonys, of passing Laws of a nature not warranted by Your Majestys Instruclions, which lake immediate effect, and continue in Force till your Majestys Pleasure be signified 10 the contrary." (Acts of the Privy Council of England, Colonial Series, V, 25I). 
and juries hesitated and disagreed. In no instance did a clergyman recover the balance of salary for which he was suing; but the five recorded suits, with their various appeals, show striking differences.

The first case to come to actual trial was that of the Reverend Alexander White, before the King William County Court, in August, I762. At the request of the Parish Collectors, Governor Fauquier sent the original copy of the disallowance order of August, 1759, together with former disallowances for purposes of comparison. It was a matter of common knowledge that the Governor regarded the order respecting the TwoPenny Act as an ordinary dissallowance. "The court took the hint," and instructed the jury that in their opinion the Act of 1758 had been valid, since word of its repeal had come only after it had expired. The court left the final decision of this question of law to the jury. Counsel for White urged the distinction between the repeal of a law under which no action had in fact been taken, and the disallowance of an act which had already had its full effect. The omission of the word "repeal" in the Council's order was emphasized; and the inherent injustice of the measure was pointed out, but all to no effect. The jury found for the Parish Collectors, and White could only appeal to the General Court. ${ }^{\text {. }}$

The Reverend Thomas Warrington had brought suit even before White, but the case came up before the York County Court somewhat later. This time, the jury awarded substantial damages against the Collectors. The justices, however, held that the law of 1758 had been valid, and refused to allow the judgment to be entered up. Warrington also appealed to the General Court."

A third suit was that started April 1, 1 762, by the Reverend James Maury, in the Hanover County Court. Counsel for the Collectors set up the act of I758 in bar. The plaintiff demurred, insisting that this law had never been binding,

\section{'Authority for this trial is the letter in Perry, pp. 479-82.}

${ }^{2}$ Perry, p. 436; Henry's Ilenry, I, 34. Camphell, p. 514, says the suit wan in Elizabeth City Conuty. 
and on November 5, 1763 , the court sustained the demurrer. This was the first and only time that the Two-Penny Act was judicially declared invalid, because ontside the competence of the legislature. It was before a special jury at the December court, called to fix the amount of the damages, that Patrick Henry made his incendiary speech, and secured a verdict of one penny against his clients. It is quite true, as is frequently. pointed out, that technically Henry had no business to argue the law in the case. The court had ruled on the law, and the only question before the jury was the amount due Mr. Maury. The further conclusion that Henry had no law on his side is an entirely different matter. While his attack on the established clergy was entirely gratuitous and irrelevant, his argument that "the act of 1758 had every characteristic of a good law" was perfectly sound. As to his contention that " a King by disallowing Acts of this salutary nature, from being the father of his people degenerated into a Tyrant, and forfeits all right to his subjects' obedience," it seems probable that the reference was rot to ordinary disallowances at all. The real issue was the alleged right of the king to declare a law void from its inception, a right hitherto never heard of in Virginia. However inflammatory Henry's language may have been, the position which he was defending was essentially the conservative one. Again the disappointed parson could only appeal. ${ }^{x}$

In 1764 , the Reverend Patrick Henry, the orator's uncle, started suit in Hanover County. This continued until the General Court had passed on the fundamental issues involved, and was then dismissed. ${ }^{2}$

In all the litigation, however, the crucial case was the one instituted in behalf of the Reverend John Camm. Since his parish was in Williamsburg, suit was brought originally in the General Court, October IO, 1759. The court, it would seem deliberately, ${ }^{3}$ delayed a decision, and the proceedings dragged

\footnotetext{
1 On Maury's Case: Fontaine, (ed. A. Maury) Memoirs of a Iluguenot Family, p. 419 , gives Maury's letter to Camm. Wirt's lenry is hased on testimony of persons present, bu given years later. Henry's Ilenry uses all material avalalle. Rolinson's letter in Perry, p. $497 \mathrm{ff}$, is hased on Maury's letter to Camm.
}

'Henry's Henry, I, 45.

${ }^{3}$ Perry, p. 475. 
along until April I0, I 764, when by a vote of five to four the Act of 1758 was upheld, and judgment was given against Camm. Two members of the court refused to vote, on the ground that they were Camm's parishioners. ${ }^{x}$ The Governor, who needed to vote only in case of a tie, publicly expressed his approval of the decision. ${ }^{2}$

Camm appealed to the Privy Council. In this of course he was fighting the cause of all the ministers. The assembly, in turn, realizing the extent to which their legislative independence would be curtailed by an adverse decision, undertook the expense of defending the Collectors. ${ }^{3}$ The case was referred to a Committee of the Privy Council, and there argued at length. In accordance with the Committee report, the Council dismissed Camm's appeal. The decision was not at all on the merits of the case, but on the technical ground that the original suit should have been brought as an action of debt instead of trespass upon the case. It was generally understood that this was a mere pretext for evading the issue. Presumably it was regarded as highly inexpedient to risk offending colonial opinion, already dangerously excited over the Stamp Act controversy. ${ }^{4}$

The General Court of Virginia calmly accepted this technical victory as a complete vindication of their position, and dismissed the pending appeals of White, Warrington and Maury. ${ }^{5}$ Naturally enough, the clergy were bitterly disappointed, and talked

1 The two Mr. Nelsons. One at least was thought to faror the clergy's position. (Perry, pp. 495, 514). Prohally they were glad to escape the responsilibity of voting. Meade, Old Churches, I, 218, thinks both favored the clergy. On the case before the General Court see, further, Camm's Brief and Respondents' Brief; Canı]. bell, p. 512: Perry, 1P. 495, 496.

2 Perry, pp. 495, $5^{13}$.

${ }^{3}$ Perry, p. 475.

4 From the Acts Privy Council, Colonial, IV, 699. The date would seem to be 1765 ; the Briefs as printed were for 1765 , but one is altered 101766 ; from letters in Perry, pp. 520, 524 the date of final action hy the Council appears to have been 1767 . On Privy Council's action, see Perry, pp. 525-30; and mss, endorsement on Respondents' Brief: "Judgment affirmed for the Respondents (the action being misconceived ) . . . No determination, as to the disallowance of the Act of Assembly 1758, $w$ [hethe] $r$ it avoided the act ab initio, nor whether it was void in Law as heing against natural Justice.",

${ }^{5}$ Perry, pp. 527, 530. 
for several years of renewing the contest in the courts, but nothing definite was done, and the whole matter was lost sight of in the excitement of new issues.'

On the basis of the arguments in these different suits, supplemented by contemporary letters and pamphlets, it is possible to summarize the opposing views as to the validity of the TwoPenny Act, as follows.

Against the original validity of the Act it was urged: (a) that the legislature of Virginia, owing its very existence to the royal prerogative, was not an independent but a subordinate body. It had only such powers as the king chose specifically to confer, and it was strictly subject to such limitations as he saw fit to impose. ${ }^{2}$ Certain of these limitations were expressed in the governor's commission, in the clause which anthorized him to pass certain laws with the consent of the assembly. Thus, laws should not be repugnant to those of England, and they must be submitted promptly to the king for approval or disallowance. $^{3}$ But the governor's commission also referred him to his instructions, " and consequently such instructions are, by such reference, incorporated with and made Part of the Commission." 4

(b) The sixteenth article of the governor's instructions forbade him to sign any "Act for repealing any other passed within the Colony whether the same had or had not received the Royal Approbation, unless a Clause was inserted . . . suspending . . . the Execution thereof until his Majesty's Pleasure should be known."

(c) The assembly had long known of this restriction, and had recognized that it was binding on them as well as on the governor; for in 1752 they had formally and specifically admitted that a law once confirmed "cannot by the legislature here be revised, altered, or amended" without a suspending clause. ${ }^{6}$ They therefore had petitioned for a modification of

\footnotetext{
${ }^{1}$ Perry, Hi. 524, 530.

"Perry, p. 515.

"Camm's brief, PP. 211-212.

thid., p. 220; Perry, p. 512.

"( puoted in Camm's Brief, PJ' $217-21 \mathrm{~S}$.

"Hening, $\mathrm{V}$, 435, note; Canm's Brief, p, 222.
} 
along until April I0, I764, when by a vote of five to four the Act of 1758 was upheld, and judgment was given against Camm. Two members of the court refused to vote, on the ground that they were Camm's parishioners. ${ }^{x}$ The Governor, who needed to vote only in case of a tie, publicly expressed his approval of the decision. ${ }^{2}$

Camm appealed to the Privy Council. In this of course he was fighting the cause of all the ministers. The assembly, in turn, realizing the extent to which their legislative independence would be curtailed by an adverse decision, undertook the expense of defending the Collectors. ${ }^{3}$ The case was referred to a Committee of the Privy Council, and there argued at length. In accordance with the Committee report, the Council dismissed Camm's appeal. The decision was not at all on the merits of the case, but on the technical ground that the original suit should have been brought as an action of debt instead of trespass upon the case. It was generally understood that this was a mere pretext for evading the issue. Presumably it was regarded as highly inexpedient to risk offending colonial opinion, already dangerously excited over the Stamp Act controversy. ${ }^{4}$

The General Court of Virginia calmly accepted this technical victory as a complete vindication of their position, and dismissed the pending appeals of White, Warrington and Maury. ${ }^{5}$ Naturally enough, the clergy were bitterly disappointed, and talked

'The two Mr. Nelsons. One at least was thought to favor the clergy's positin. (Perry, pp. 495, 514). Probably they were glad to escape the responsibility of voting. Meade, Old Churches, I, 2 I 8 , thinks both favored the clergy. On the case before the General Court see, further, Camm's Brief and Respondents' Brief: Camp. bell, p. 512; Perry, pp. 495, 496.

2 Perry, pp. 495, $5^{1} 3$.

3 Perry, p. 475.

${ }^{4}$ From the Acts Privy Council, Colonial, IV, 699. The date would seem to be 1765 ; the Briefs as printed were for 1765 , but one is altered to 1766 ; from letters in Perry, pp. 520, 524 the date of final action by the Council appears to have been 1767 . On Privy Council's action, see Perry, pp. 525-30; and mss. endorsement on Respon. dents' Brief: "Judgment affirmed for the Respondents (the action being misconceived) . . . No determination, as to the disallowance of the Act of Assembly $175^{8}$, w[hethe] $\mathrm{r}$ it avoided the $a c t$ ab initio, nor whether it was void in Law as heing against natural Justice."

'Perry, pp. 527, 530. 
for several years of renewing the contest in the courts, but nothing definite was done, and the whole matter was lost sight of in the excitement of new issues.'

On the basis of the arguments in these different suits, supplemented by contemporary letters and pamphlets, it is possible to summarize the opposing views as to the validity of the TwoPenny Act, as follows.

Against the original validity of the Act it was urged: (a) that the legislature of Virginia, owing its very existence to the royal prerogative, was not an independent but a subordinate body. It had only such powers as the king chose specifically to confer, and it was strictly subject to such limitations as he saw fit to impose. ${ }^{2}$ Certain of these limitations were expressed in the governor's commission, in the clause which authorized him to pass certain laws with the consent of the assembly. Thus, laws should not be repugnant to those of England, and they must be submitted promptly to the king for approval or disallowance. ${ }^{3}$ But the governor's commission also referred him to his instructions, " and consequently such instructions are, by such reference, incorporated with and made Part of the Commission." 4

(b) The sixteenth article of the governor's instructions forbade him to sign any "Act for repealing any other passed within the Colony whether the same had or had not received the Royal Approbation, unless a Clause was inserted . . . suspending . . . the Execution thereof until his Majesty's Pleasure should be known." s

(c) The assembly had long known of this restriction, and had recognized that it was binding on them as well as on the governor; for in 1752 they had formally and specifically admitted that a law once confirmed " cannot by the legislature here be revised, altered, or amended" without a suspending clause. ${ }^{6}$ They therefore had petitioned for a modification of

\footnotetext{
'Perry, pl. 524, 530.

"Camm's Brief, pp. 21 I-2 I2.

"Quoted in Camm's Brief, pp. $217-218$.

'Hening, V, 435, note; Canm's Brief, p. 222.
}

${ }^{2}$ Perry, p. 515 .

+ Ilid., p. 220; Perry, p. 512. 
this very instruction, so as to allow them to pass emergency amendments; ${ }^{1}$ but the King in Council, March 7, I753, had declared "it was by no means advisable . . . to Authorize the Council and House of Burgesses" to have this power. ${ }^{2}$

(d) But the Act of $175^{8}$ amended and partially repealed the Act of 1748 , which had been confirmed; and it contained no suspending clause. Therefore the action of the assembly was entirely without authority, and the governor's signature was worthless. For acts once confirmed could not be amended by a lesser power than that which had established them-the joint action of king and assembly. ${ }^{3}$ In consequence the act in question was at the time of making and thenceforth null, void, and no law at all.4

(e) Accordingly, when the Virginia courts were called upon to choose between the essentially contradictory acts of 1748 and 1758 , it was their duty to disregard the latter as being beyond the constitutional power of the legislature to enact. ${ }^{5}$

(f) The Privy Council believed the act was originally void, and they expected the Virginia courts to disregard it. By omitting the word "repeal" from their order, they purposely distinguished between this instance and an ordinary disallowance. $^{6}$ They declared that if the question came before them in their judicial capacity, they would certainly declare the TwoPenny Act " no law" and "void ab initio."

(g) Any other view would make the disallowance utterly "nugatory," since the law had expired before its disallowance

Hening, V, 435, note. They asserted a right, however, to amend laws not formally ratified.

${ }^{2}$ Acts of the Privy Council, Colonial Series, IV, 175; a mss. copy is included in Camm's Brief, p. 271.

"Camm's Brief, p. 221. In 1696 Hartwell, Blair and (hilton wote that when laws are "once ratified ly the King, they can only be sepealeci by the King and General Assembly." Cal. St. Papers, Col., $1696-7$, p. 654. Carter and Bland admit that this was the general rule; Carter, Letter, p. 6; Hland, Letter, p. IS; I'erry, pp. 465,487 .

thid., p. 221.

${ }^{3}$ Perry, pp. $4{ }^{4} \mathrm{I}, 510$.

"Wirt's Henry', p. 40; Ierry, P. $48 \mathrm{I}$.

'Perry, pp. 490, 5ro; Camm's Brief, p. 217. 
was known in Virginia." But "this divests his Majesty of his whole Prerogative, for by this Means the Assembly, by annual temporary Acts, which cannot be disallowed herc till they are expired, might elude all the Acts which have received the Royal Confirmation." This would involve a radical change in the British constitution, and would be a dangerous step towards "civil independency:"

(h) There are precedents for such action by the courts; in particular, "the Privy Council, on hearing an Appeal between Winthrop and Lechmore [sic] from Connecticut, I 727 , judicially declared two Acts of Asscmbly passed in that Province void." 3

(i) But entirely apart from all these considerations, "the Council and Assembly cannot make Laws like this of $175^{8}$, repugnant to Reason, and fundamentally unjust." Lord Hardwick, of the Council, and for twenty years Lord Chancellor, had declared the law invalid "from its manifest Injustice, if there had been no other Objection to it." " The law was "contrary to natural Justice \& Equity," and therefore void, since it was retroactive, depriving the clergy of a part of the salary which they had already earned in 1757-8. This was "to sap the foundations of property." 5

In defense of the validity of the act it was contended: (a) that as free-born English subjects, Virginians " must necessarily have a legal Constitution, that is, a Legislature, composed in part, of the Representatives of the People, who may enact laws for the internal Government of the Colony." 6 "From the nature of the English Constitution, it is evident that the Legislature of the Colony have a right to enact any Law they shall think necessary for their internal Government." 7 From the fundamental principles of the "Constitution [an] Act must have the force of Law, when passed by the Governor." 8 This

\footnotetext{
${ }^{1}$ Camm's Brief, p. 222; Ferry, 1. 516 . "2'erry, p. 511.

${ }^{3}$ Camm's Briel, p. 22r. $\quad$ lioid., pp. $217,22 \mathrm{r}$.

${ }^{5}$ Perry, pp. 441, 465, 490, 514.

"Bland, Colonel Dismounted, in Wm. and Mary Quarterly, vol. 19, p. 33.
ibial., p. 34 .
${ }^{2}\left[b i a\right.$, pp. $37,3^{8}$. 
natural right to local self-government had been confirmed by grants from the crown in the charters to the Virginia Company of 1606,1609 and 1612 , by the ordinance of 1621 , and by the proposed charter of $1675 .^{\mathrm{x}}$ Once granted, "if what Lord Coke says in Calvin's case is true," such a right could not be altered or abrogated. ${ }^{2}$

(b) Thus, " in accordance with the original Constitution of Virginia," the king's commission to Loudon authorized him, with the consent of the assembly, to make any laws not repugnant to those of England. 3

(c) The king indeed reserved the right to disallow laws; but by the express language of the governor's commission, and by unbroken usage, disallowance took effect only from the time notice thereof was published in the colony, even when disallowance had been due to breach of the governor's instructions. ${ }^{4}$

(d) The governor's instructions were for his private guidance only, and were in no sense legally binding on the assembly. They were not public instruments, nor were their contents known except in part. Never having been promulgated, they could not have the force of law without violating the fundamentals of the British constitution, nor did the king intend them for more than a guide to the governor in the exercise of his discretionary powers. ${ }^{5}$ If the governor violated his instructions, it was a matter for him to settle with his royal master. ${ }^{6}$ But the fact that he had rendered himself liable to punishment, did not invalidate his signature.7 Granting in general that the king's instructions should be respected, still grave and unforeseen emergencies might make instant action imperative, and hence lawful. Previous governors had assented to laws in violation

\footnotetext{
'Respondents' Brief, pp. 225-32: Bland, loc cit., pp. 35, 36; Perry, p. 495. Henry's Henry, I, fo.

"Bland, ioc. cit., p. 37.

"Respondients' Irief, p. $26_{3}$.

' libid., pp. $255,263$.

${ }^{5}$ Bland, loc. cit., p. $3^{S}$; R. II. Lee, in Camplell, p. 513 .

"Perry, p. 521.

'Bland, loc. cit., lp. $3^{8-40 .}$

${ }^{8}$ Bland, Letter, p. I8; Carter, Letter, pp. 6-7; Campbell, p. 5 Io; Perry, p. 467.
} 
of the letter of their instructions. Sometimes they had been reproved and the laws disallowed; sometimes the laws had been confirmed. But never had laws thus disallowed been declared void $a b$ initio. The very fact that governors had been sharply reproved for violating their instructions showed that the laws thus assented to were not mere nullities. ${ }^{\mathrm{x}}$

(e) The law of October 12,1758 , had been regularly passed, and assented to by the governor in due form. It was not disallowed until August 10, I 759, and notice was not received until June 27, I 760 . "Till this Time therefore it was a good and valid Law in the colony, and the Inhabitants obliged to conform to it as such nor could any one justify the acting contrary to it." 2

(f) The Cotncil's disallowance of the Act was in the regular form, and did not expressly or by implication declare the law void ab initio.3

(g) The question of the invalidity of the Act because of its alleged injustice was not "pertinent to the present Question." 4 The Legislature was the judge of the justice of its laws; otherwise the colonists were not free men. ${ }^{5}$ As a matter of fact, however, the law was not unjust. The emergency entirely justified it. It was general in terms, and did not apply specifically to the clergy. Furthermore, at two pence a pound, the salaries of the ministers were generously above the average of past years, and larger than it had ever been intended they should be. ${ }^{6}$

\footnotetext{
'Bland, loc. cit., pp. 40-4I. This is an important point. Governors had constantly violated their instructions. (Greene, Provincial Governor, pp. 164-165.) Instances of signing laws contrary to instructions appear in Acts Privy Council Colonial, III, 343,617; IV, 59, 256, 30S, 449, 4SS-9, 674, especially no. 155; Virginia Laws of $174 \mathrm{~S}, \mathrm{~V},{ }_{3} \mathrm{~S}-9,50,59,215,251,395,397,577,5$ So, $5 S_{3}, 586$; Archives of the State of New Jersey, Ist. Ser., X, 43; Mass. Acts and Resolves, II, 127, 593;

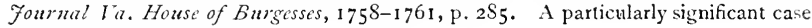
is in Cal. State Papers, Col., I661-1ó68, p. 759.

'Respondents' Brief, p. 264 .

${ }^{3}$ IJid., p. 268, quoting the order: R. II. Lee, in Camplell, p. 513.

4 Respondents' Brief, p. 267.

s Perry, p. 495.

${ }^{6}$ Lland, Letter, p. I4 ff; Carter, Letter, pp. 5, 42, 51 ; Respondents' Brief, pp. $237-238$.
} 
These arguments bring out clearly the logical steps by which the Two-Penny Cases led back to fundamental constitutional issues. Since the Act of 1758 could not have been affected by an ordinary disallowance. its validity in May, 1759, depended solely on the original right of the governor and assembly to pass it. This in turn involved the question whether the king's will as expressed in his instructions to the governor constituted a fundamental limitation on the legislative power of the governor and the assembly, a limitation, that is, of such a nature as to render null and void all actions which transgressed it. In the absence of clear precedents, this point could be determined only by a choice between radically different theories as to the source and nature of the assembly's legislative power, and of the extent of the governor's discretion.

In every one of the court decisions against them, the clergy naturally felt that public opinion, prejudice against the established church, official pressure, personal animosities, and selfish interests were arrayed against them. ${ }^{{ }^{2}} \quad$ Futhermore, in yielding to political considerations, and refusing a decision on the merits of the case, it was felt that the Privy Council had been guilty of a breach of faith. ${ }^{2}$

For us, the fact that the highest court of appeals avoided pronouncing on the constitutional question involved, robs the whole controversy of some of its interest. It is clear that the Council were in an embarrassing position. Undoubtedly they would have preferred to declare the Two-Penny Act invalid. But entirely apart from the political dangers of such a step, it is difficult to see how, on strictly legal grounds, they could have done so. Winthrop $v$. Lechmere had, it is true, asserted their right to declare a colonial law void from the beginning if it transcended charter limitations. ${ }^{3}$ But it had never been established that an instruction to a governor was at all comparable to a charter limitation on the legislature. On the other hand, the principle that a colonial law was valid until its disallowance was made known was a long-established one.

'Ierry, pp. 469, 477, 479, 48I-2, 484, 496-7.

${ }^{2}$ Perry, pp. 520-521.

$3_{2}$ Mass. Hist. Soc. Coll, I, 8, 137. Thayer, Cases on Constitutional Law, I, 34 . 
It is difficult therefore to avoid the conclusion that the Virginia courts were entirely justified in deciding as they did. Only by declaring the law of 1758 void from its passage as violating a higher law-the king's instructions, and natural justice-could they have decided otherwise; and it was certainly too early to expect that judges would do this as a matter of course.

The present doctrine of the power of courts to declare a law unconstitutional, rests on three assumptions :

First, that there is a distinction between ordinary and fundamental law. The power of the legislature is not absolute, but is limited by the fundamental law.

Second, when the legislature transcends the limits set to its powers by the fundamental law, its action is null and void, and no one is bound thereby.

Third, whenever in the ordinary course of administering justice, the courts encounter an apparent conflict between an ordinary act of the legislature and the fundamental law, they not only may but must consider and decide whether the ordinary law can be reconciled with the fundamental law. If they believe that no reconciliation is possible, it is their right and their duty to disregard the ordinary law entirely, deciding the case before them in all respects as if it had never existed.

In essence these three principles are clearly discernible in the Two-Penny Cases.

As to the first, it was asserted that the legislative power of the Virginia assembly was limited by the king's instructions and by the laws of natural justice.

Second, it was argued in so many words that the pretended law of 1758 was from the moment of passage null, void and no law at all, because in passing it the legislature violated both royal instructions and natural equity. Therefore no citizen was bound to obey it, nor could any official plead it in justification of any of his acts.

Third, the courts were asked to recognize and act on both of these principles. It was insisted that they should take notice of the conflict between the act of 1758 and fundamental law, as expressed in the instructions and natural equity. And they 
Were urged to decice cases as if the law of 1 ; 3 s had never exis:es.

The most stanticant sentence in Otis s spech on the llits ci Assitance was the cetaration that "An act against the Constauton is ro:d an ac: against natural equity is roid." These were sussana"y the points raised in the Virginia cases aso. In botin instances the juctes isnored the natural justice

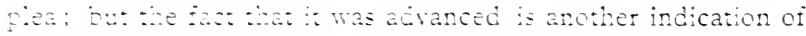

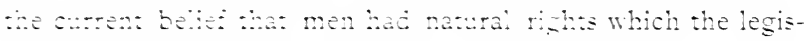

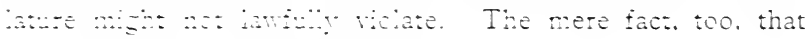

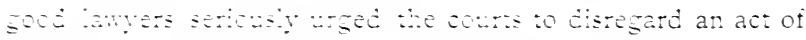

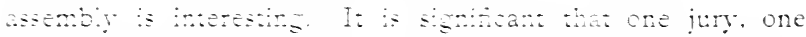

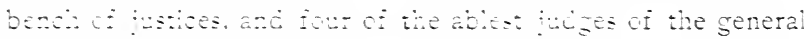

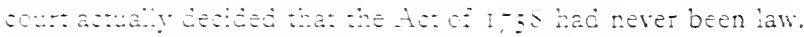

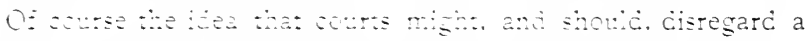

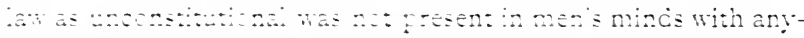

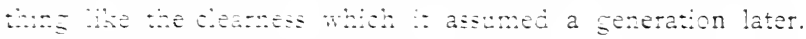

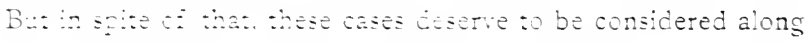

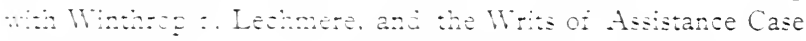

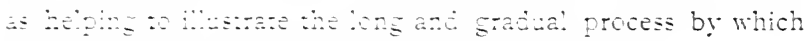

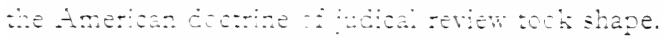

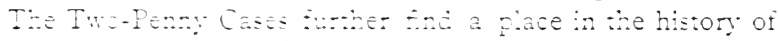

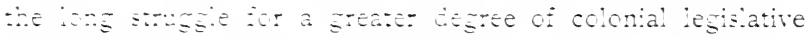

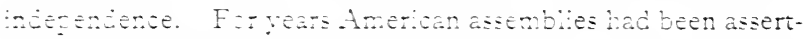

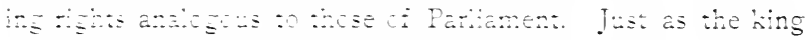

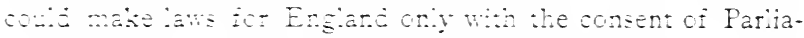

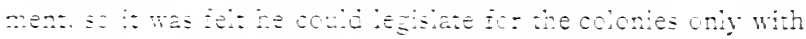
tre crasen ci he ina asserblies. Any limitation on the teeton a arton ci the representatres of the people was re-

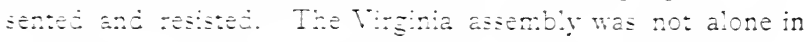

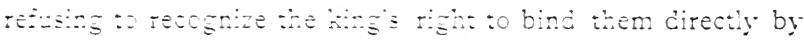

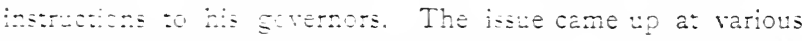

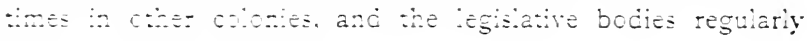
- 
The controversy over the act of 1758 thus deserves a place in the study of the pre-revolutionary period, but not primarily because it illustrated the presence of a sediticus and rebellious spirit. Its real significance lies in the fact that for six critical years it helped to bring the people of Virginia face to face with fundamental questions. The legislative freedom of their assembly was imperiled. This made necessary a clear statement and a closely reasoned defense of the American view of the constitutional place of the colonies in the Empire; and in that work Patrick Henry's speech was far less significant than the widely read pamphlets of Carter and Bland. On a small scale, the whole episode illustrates the clash of political theories which lay back of the American Revolution. The arguments by which the colonists defended the law of 1758 were exactly the same as those on which they based their resistance to king, ministry and Parliament. The principles on which they relied were the ones on which they founded their whole political system. The entire controversy, like so many other incidents in colonial history, has been too exclusively regarded as a sign of growing irritation on the part of the colonists. Its importance as an incident in the attempted working-out of a new imperial system has been too largely overlooked.

ARTHER P. SCOTT.

LNiversity of Chicago.

"the instructions represent only the irieas of the home government. They were absolutely binding, inceed, upon the royal appoirtees, but their binding force, while generally acquiesced in, was rever admitted as atsolute ty all the colonists." Tanner, E. P.. The Frovince of New Jeriey. p. I 50. 






\section{THE ACADEMY OF POLITICAL SCIENCE}

\section{IN THE CITY OF NEW YORK}

The A l-tmy of Political Science is affiated with Columbia I'r wen and is composed of men and women interested in politecomonic and sncial quesions The annual dues are five Nembers recene the Political Science Quartenly and the eching of the Azad my--iscued as Supplements to the Quar-

- and are entutie to ire admusion to all meetings, lectures and copton= under the alipices of the Academy.

finanunications regarding the Academy should be adThe secretary of the Acalemy of Political

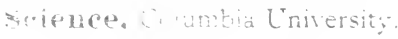

\section{THE POLITICAL SCIENCE QUARTERLY}

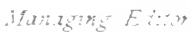

$$
\begin{aligned}
& \text { TEOMA REEL F.MELL }
\end{aligned}
$$

The Guarter!y tu - the mostimpurtant muvements of toreign poi*cs but devotes hill attention te quetions of present interest in the Lnipd States On such questions its attitude is nonpartisan. Every arte is sed; and ciery article, including those of the

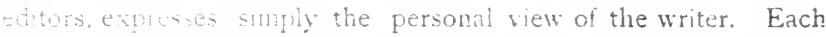

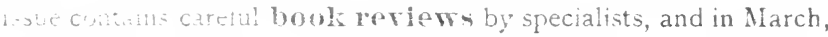

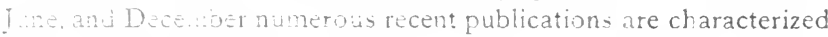
houk notes. In september is printed a Sipplement, con tring a valiable record of political events throughout the world.

Comminications in reference to articles, book reviews and Exchang- should be addre-sed to the Political sicience Quarterly, Columbia Liversity, New Iork City. Intending contributirs are recucsted to retain cupies of articles submitted, as the Fitors isclaim resonsitility for the safuty of manuscripts. If acompanted by stamps, aticles nnt found available wili be returned.

subscriptiuns should be forwarded and all business comnications addrised to the publichers, Ginm \& Company, Lincaster. Pa, or to Fifth Avenue, New York

Yearly subscription, including Supplements, five dollars: single number, not including Supplement, one dollar. Supplement containing Record of Political Everts, one dollar. Back numbers and bound volumes can be obtained from the publishers 